\title{
The U2 Small Nuclear Ribonucleoprotein Particle as an Autoantigen Analysis with Sera from Patients with Overlap Syndromes
}

\author{
Joe Craft, Tsuneyo Mimori, Tammy L. Olsen, and John A. Hardin \\ Department of Medicine, Yale University School of Medicine, New Haven, Connecticut 06510
}

\begin{abstract}
We identified eight patients whose sera contained autoantibodies to the U2 small nuclear ribonucleoprotein (snRNP), an RNA protein particle involved in the splicing of newly transcribed messenger RNA. Each of these patients had an overlap syndrome that included features of either systemic lupus erythematosus (SLE), scleroderma, and/or polymyositis. We then used these sera to characterize the autoantigenic polypeptides of the $\mathrm{U} 1$ and $\mathrm{U} 2$ snRNP particles. In immunoblots, all sera contained antibodies to the $B^{\prime \prime}$ polypeptide of the U2 snRNP.A subset of these sera that more effectively immunoprecipitated the native $\mathbf{U} 2$ particle contained an additional antibody system that recognized the $A^{\prime}$ polypeptide of this snRNP. Antibodies eluted from the $B^{\prime \prime}$ protein bound the $A$ polypeptide of the $\mathrm{U} 1$ snRNP and vice versa. Moreover, antibodies to the $B^{\prime \prime}$ polypeptide were accompanied by antibodies to the $68 \mathrm{~K}$ and $C$ polypeptides of the $U 1$ snRNP. Finally, the $A^{\prime}$ and $B^{\prime \prime}$ polypeptides remained physically associated after the $U 2$ particle was cleaved with RNase.

Thus these sera contain multiple autoantibody systems that, at one level, target two physically associated antigenic polypeptides of the $\mathrm{U} 2$ particle and, at another, target two snRNP particles which are associated during the splicing of premessenger RNA. These linked autoantibody sets provide further evidence that intact macromolecular structures are targeted by the immune response in SLE and related diseases.
\end{abstract}

\section{Introduction}

The U series of small nuclear ribonucleoprotein (snRNP) ${ }^{1}$ particles consists of uridine-rich, small RNAs and associated polypeptides. The abundant $\mathrm{U} 1$ and $\mathrm{U} 2$ snRNPs, as well as the less abundant U4, U5, and U6 snRNPs, are central elements in the splicing of newly transcribed messenger $\operatorname{RNA}(1,2)$.

This work was presented in part in abstract form (1986. Clin. Res. 34:616A).

Dr. Mimori's present address is Department of Internal Medicine, Keio University School of Medicine, 35 Shinanomachi, Shinjuku-ku, Tokyo 160, Japan.

Address reprint requests to Dr. Craft, Department of Medicine, 609 LCI, Yale University School of Medicine, 333 Cedar Street, New Haven, CT 06510.

Received for publication 1 September 1987 and in revised form 19 November 1987.

1. Abbreviations used in this paper: CPK, creatine phosphokinase; MCTD, mixed connective tissue disease; SLE, systemic lupus erythematosus; snRNP, small nuclear ribonucleoprotein.

J. Clin. Invest.

(c) The American Society for Clinical Investigation, Inc.

0021-9738/88/06/1716/09 \$2.00

Volume 81, June 1988, 1716-1724
These structures are common targets of autoimmunity in systemic lupus erythematosus (SLE) and related connective tissue disease syndromes $(3,4)$.

Structurally, the U1 snRNP consists of the U1 small RNA and at least nine associated polypeptides $(3,5-18)$. Three of these proteins, known as $68 \mathrm{~K}\left(M_{\mathrm{r}}=68,000 \mathrm{D}\right),{ }^{2} \mathrm{~A}\left(M_{\mathrm{r}}\right.$ $=33,000 \mathrm{D})$, and $\mathrm{C}\left(M_{\mathrm{r}}=22,000 \mathrm{D}\right)$ are unique to the U1 snRNP. Six additional polypeptides, $\mathrm{B}^{\prime}\left(M_{\mathrm{r}}=29,000 \mathrm{D}\right), \mathrm{B}\left(M_{\mathrm{r}}\right.$ $=28,000 \mathrm{D}), \mathrm{D}\left(M_{\mathrm{r}}=16,000 \mathrm{D}\right)$, and $\mathrm{E}-\mathrm{G}\left(M_{\mathrm{r}}=13,000\right.$ $11,000 \mathrm{D})$ are common to the U1, U2, and U4-U6 snRNPs. Anti-U1 RNP antibodies bind the U1 snRNP specific polypeptides $68 \mathrm{~K}, \mathrm{~A}$, and/or $\mathrm{C}$ while anti-Sm antibodies bind a shared epitope(s) of the $B^{\prime}, B$, and D polypeptides. The E-G polypeptides are rarely autoantigenic (16). High titers of antiU1 RNP antibodies are a hallmark of mixed connective tissue disease (MCTD) (19-23); in lower titers, they are also common in SLE, although often in conjunction with anti-Sm antibodies (21-24). The latter are pathognomonic for SLE.

The U2 snRNP consists of the U2 small RNA, six shared polypeptides noted above (B', B, D-G), and two unique polypeptides known as $\mathrm{A}^{\prime}\left(M_{\mathrm{r}}=31,000 \mathrm{D}\right)$ and $\mathrm{B}^{\prime \prime}\left(M_{\mathrm{r}}=28,500 \mathrm{D}\right)$ $(9,12-14,18,25,26)$. Anti-U2 antibodies specific for the $A^{\prime}$ and $B^{\prime \prime}$ polypeptides were initially described by Mimori and co-workers in 1984 in one patient with scleroderma-polymyositis overlap syndrome (25). More recently, anti-U2 antibodies have been described in an additional four patients without an identified disease association (26), and two patients with psoriasis and Raynaud's phenomenon (27). Finally, Pettersson and colleagues have identified anti-U2 RNP antibodies in the sera of six patients with MCTD (28).

These observations raised the possibility that anti-U2 RNP antibodies might be markers for a particular subset of patients. To explore this possibility further, we sought these antibodies in sera from 229 patients with various rheumatic diseases. Our results demonstrate that anti-U2 antibodies exhibit linkage with anti-U1 RNP antibodies and occur mainly in sera from patients with overlap syndromes that often includes myositis. Two types of anti-U2 specific sera were identified: one class contained antibodies directed against the $B^{\prime \prime}$ polypeptide alone, the other contained antibodies to both the $A^{\prime}$ and $B^{\prime \prime}$ polypeptides.

\section{Methods}

Sera. Sera were obtained from 229 patients (125 Japanese, 104 American) with connective tissue diseases. One of these sera (from patient Ya; serum 4 in Table II) is the prototype anti-U2 RNP serum first identified by Mimori et al. (25); two sera with known anti-U2 antibodies were obtained from other investigators. Patients with SLE and scleroderma met revised and preliminary American Rheumatism As-

2. Based upon the deduced amino acid composition obtained from the DNA sequence of this polypeptide, its actual molecular mass is $70 \mathrm{kD}$ and thus it is also known as 70K (see Theissen et al. [51]). 
sociation (ARA) criteria, respectively $(29,30)$. The diagnoses of MCTD and polymyositis were based upon accepted clinical criteria $(20,28,31)$ and, in addition for MCTD, the presence of anti-RNP autoantibodies without anti-Sm by double immunodiffusion. Patients with other overlap syndromes met criteria for SLE and/or scleroderma and had evidence for myositis, as determined by proximal muscle weakness and elevated creatine phosphokinase (CPK) levels. As an initial screen, all sera were assayed by immunoprecipitation of ${ }^{32} \mathrm{P}-\mathrm{la}-$ beled HeLa cell extracts (3).

Immunofluorescence and immunodiffusion. Indirect immunofluorescence using commercial Hep-2 cell substrates (Immunoconcepts, Sacramento, CA) (25) and Ouchterlony double immunodiffusion using calf thymus extract were performed as previously outlined (32).

Preparation of radiolabeled cell extracts. HeLa cells were maintained and radiolabeled as previously described (25). Briefly, for RNA analysis, $2 \times 10^{5}$ cells $/ \mathrm{ml}$ were labeled with $\left.{ }^{32} \mathrm{P}\right]$ orthophosphate (10 $\mu \mathrm{Ci} / \mathrm{ml}$ cells; Amersham Corp., Arlington Heights, IL) in phosphatefree essential medium for $12-14 \mathrm{~h}$. For protein studies, $2 \times 10^{5} \mathrm{cells} / \mathrm{ml}$ were incubated with $\left[{ }^{35} \mathrm{~S}\right]$ methionine $(5 \mu \mathrm{Ci} / \mathrm{ml}$ cells; Amersham Corp.) in methionine-deficient medium for $14 \mathrm{~h}$. Cells were then harvested and washed once in cold Tris-buffered saline $(10 \mathrm{mM}$ Tris- $\mathrm{HCl}$, $150 \mathrm{mM} \mathrm{NaCl}, \mathrm{pH} 7.5)$. After resuspension in NET-2 buffer $(50 \mathrm{mM}$ Tris- $\mathrm{HCl}, 150 \mathrm{mM} \mathrm{NaCl}, 0.05 \%$ Nonidet P-40, pH 7.5) at $2 \times 10^{5}$ cells $/ 10 \mu 1$, cells were sonicated (Branson Sonic Power Co., Danbury, CT) on ice three times for $40 \mathrm{~s}$ each. Sonicates were clarified by centrifugation at $12,000 \mathrm{~g}$ for $20 \mathrm{~min}$ and the supernatants were used immediately as a source of antigen.

Immunoprecipitation procedures. Immunoprecipitation of radiolabeled cell extracts was performed as described $(3,11,25)$ with modifcations (33). $10 \mu$ of patient serum was incubated overnight at $4 \mathrm{C}$ with $2 \mathrm{mg}$ of preswollen protein A-Sepharose (Pharmacia Fine Chemicals, Piscataway, NJ) in $500 \mu$ l of immunoprecipitation buffer (IPP: $10 \mathrm{mM}$ Tris- $\mathrm{HCl}, 500 \mathrm{mM} \mathrm{NaCl}, 0.1 \%$ Nonidet P-40, pH 7.5). Antibodycoated beads were then washed three times in IPP and resuspended in $400 \mu \mathrm{l}$ of NET-2. In certain experiments, patient sera were diluted 1:100 and 1:1,000 in IPP before incubation with the protein A-Sepharose beads. For analysis of nucleic acids, beads were combined with $100 \mu \mathrm{l}$ of ${ }^{32} \mathrm{P}$-labeled extract $\left(2 \times 10^{6}\right.$ cells $)$ and incubated with rotation for $1 \mathrm{~h}$ at $4 \mathrm{C}$. After three washes with NET-2, the beads were resuspended in $300 \mu \mathrm{l}$ of this buffer, $15 \mu \mathrm{l}$ of $20 \%$ SDS, $30 \mu \mathrm{l}$ of $3 \mathrm{M}$ sodium acetate (pH 5.2), and $2 \mu \mathrm{l}$ of yeast tRNA (Sigma Chemical Co., St. Louis, $\mathrm{MO} ; 10 \mathrm{mg} / \mathrm{ml}$ ). Radiolabeled nucleic acids were then extracted with phenol/chloroform/isoamyl alcohol (50:50:1) containing $0.1 \% 8$ hydroxyquinoline, precipitated by ethanol, fractionated on $10 \%$ polyacrylamide-7M urea gels, dried, and detected by autoradiography.

For analysis of proteins, antibody-coated beads were combined with $50 \mu 1$ of ${ }^{35} \mathrm{~S}$-labeled extracts $\left(1 \times 10^{6}\right.$ cells $)$ and incubated with rotation for $1 \mathrm{~h}$ at $4 \mathrm{C}$. After three washes with NET-2, the beads were resuspended in SDS-sample buffer (2\% SDS, 5\% 2-mercaptoethanol, $10 \%$ glycerol, $62.5 \mathrm{mM}$ Tris- $\mathrm{HCl}, 0.005 \%$ bromophenol blue, $\mathrm{pH} 6.8$ ). The bound proteins were released into sample buffer using heat $\left(90^{\circ} \mathrm{C}\right.$ for $5 \mathrm{~min}$ ). The proteins were fractionated on 15\% SDS-polyacrylamide gels (34) (40:1.33 acrylamide: bisacrylamide), which were enhanced with $0.5 \mathrm{M}$ sodium salicylate and dried; labeled proteins were then detected by autoradiography.

$R$ Nase digestion experiments. In certain experiments, ${ }^{35} \mathrm{~S}$-labeled HeLa extracts bound to antibody-coated protein A-Sepharose beads were digested with pancreatic ribonuclease (Boehringer Mannheim, Indianapolis, IN). In these experiments, beads were washed with NET-2 as described previously and resuspended in $100 \mu \mathrm{l}$ of NET-2 containing $5 \mathrm{mM} \mathrm{MgCl} 2$ and ribonuclease (final concentration, 1 $\mathrm{mg} / \mathrm{ml}$ ). Samples were then incubated at $25^{\circ} \mathrm{C}$ for 30 min with intermittent gentle agitation. Control samples were handled identically, except for the addition of ribonuclease. Beads were then pelleted, supernatants were precipitated with trichloroacetic acid (TCA), and the beads were washed four times with NET-2. Beads and TCA precipitates were then resuspended in SDS-sample buffer as outlined above and analyzed by SDS-PAGE (34).
Preparation of substrates for immunoblots. Enriched snRNPs were prepared by immunoaffinity chromatography as described (17) with modifications. HeLa cells $\left(7.5 \times 10^{5}\right.$ cells $\left./ \mathrm{ml}\right)$ were harvested, washed in cold Tris-buffered saline, and sonicated in $0.35 \mathrm{M} \mathrm{NaCl}, 10 \mathrm{mM}$ Tris- $\mathrm{HCl}$ (pH 7.5), $1.5 \mathrm{mM} \mathrm{MgCl}$, and $0.2 \mathrm{mM}$ phenylmethylsulfonyl fluoride. The extract wás centrifuged at $10,000 \mathrm{~g}$ for $2 \mathrm{~h}$. Supernatants were then passed through Aff-Gel 10 (Bio-Rad Laboratories, Richmond, CA) columns previously coupled with human IgG $(5-7 \mathrm{mg} / \mathrm{ml}$ wet gel) isolated from patient sera with high activity of anti-U2 (patient 1 , Table II), anti-U1 RNP, or anti-Sm. After washing, bound material was eluted from columns with $6 \mathrm{M}$ urea, $0.1 \mathrm{M} \mathrm{NaCl}$, and 10 $\mathrm{mM}$ Tris- $\mathrm{HCl}$ (pH 7.5). Eluted material was then concentrated by the addition of $100 \%$ TCA (final concentration $25 \%$ ) followed by two cold acetone washes or by precipitation with $95 \%$ cold ethanol. After dessication, precipitated samples were then dissolved in SDS-sample buffer, heated to $90^{\circ} \mathrm{C}$ for five minutes, and used as substrates for immunoblots.

Immunoblots. snRNP proteins were fractionated on 12.5\% SDS gels, transferred to nitrocellulose sheets (Schleicher \& Schuell, Inc., Keene, NH) by electrophoresis in a buffer containing $25 \mathrm{mM}$ Tris, 192 $\mathrm{mM}$ glycine, $0.1 \%$ SDS, and $25 \%$ methanol $(16,25,35)$. Nitrocellulose sheets were then blocked for at least $1 \mathrm{~h}$ in phosphate-buffered saline (PBS: $150 \mathrm{mM} \mathrm{NaCl}, 10 \mathrm{mM}$ phosphate, $\mathrm{pH}$ 7.4) containing 3\% bovine serum albumin (BSA; RIA grade; Sigma Chemical Co.) and $1 \%$ human hemoglobin (Sigma Chemical Co.). After rinsing in PBS, nitrocellulose papers were incubated in patient and control sera diluted 1:100 in PBS- $0.05 \%$ Tween 20 (PBS-T) for $45 \mathrm{~min}$. Strips were then washed in PBS-T, incubated with ${ }^{125}$ I-labeled protein A in PBS-T (2 $\times 10^{5} \mathrm{cpm} / \mathrm{ml}$ ) for $45 \mathrm{~min}$, rewashed, dried, and exposed to XRP film (Eastman Kodak Co., Rochester, NY) overnight at $-70^{\circ} \mathrm{C}$. A known positive control serum and a serum from a normal volunteer were included with each immunoblot.

Elution of antibodies from immunoblots. In certain experiments, antibodies bound to protein bands on nitrocellulose strips were eluted as previously described (36). As controls, antibodies were eluted from areas of nitrocellulose that did not contain protein bands (blank areas) or from bands not containing U1 or U2 snRNP proteins.

Two-dimensional immunoblots. Ethanol-precipitated snRNP proteins were fractionated for $1,500 \mathrm{~V}-\mathrm{h}$ by nonequilibrium $\mathrm{pH}$ gradient electrophoresis as previously described (37). Second-dimension electrophoresis was via $10 \%$ SDS-polyacrylamide gels. For comparison, snRNP polypeptides were fractionated in one dimension on the same gel. Immunoblots were performed as outlined above, except that some nitrocellulose strips were probed sequentially with two sera of different antibody specificities. In these experiments, specific IgG from the first serum was detected by ${ }^{125}$ I-protein $A$ and autoradiography. Nitrocellulose papers were then rehydrated in PBS, blocked again in BSA-hemoglobin, exposed to the second serum and ${ }^{125}$ I-labeled protein $A$, and autoradiography performed a second time.

\section{Results}

Initial screen for anti-U2 antibodies. Among 229 patients with various rheumatic diseases we identified eight whose sera immunoprecipitated both U1 and U2 snRNPs from extracts of ${ }^{32}$ P-labeled HeLa cells (Fig. 1). A control anti-U1 RNP serum (lane 3) only immunoprecipitated the U1 RNA (via binding to proteins that are unique to the U1 snRNP particle) while a control anti-Sm serum (lane 4) immunoprecipitated the U2, U1, and U4-6 RNAs (via recognition of the $B^{\prime} / B$ and $D$ polypeptides that are common to all five of these snRNP particles). In contrast, seven of the eight test sera only immunoprecipitated the U1 and U2 snRNPs (sera 1, 2, and 4-8; lanes 5-10 and lanes 13-28). This observation suggested that these sera lacked anti-Sm antibodies; instead, they likely contained one population of antibodies specific for the U1 snRNP and an- 


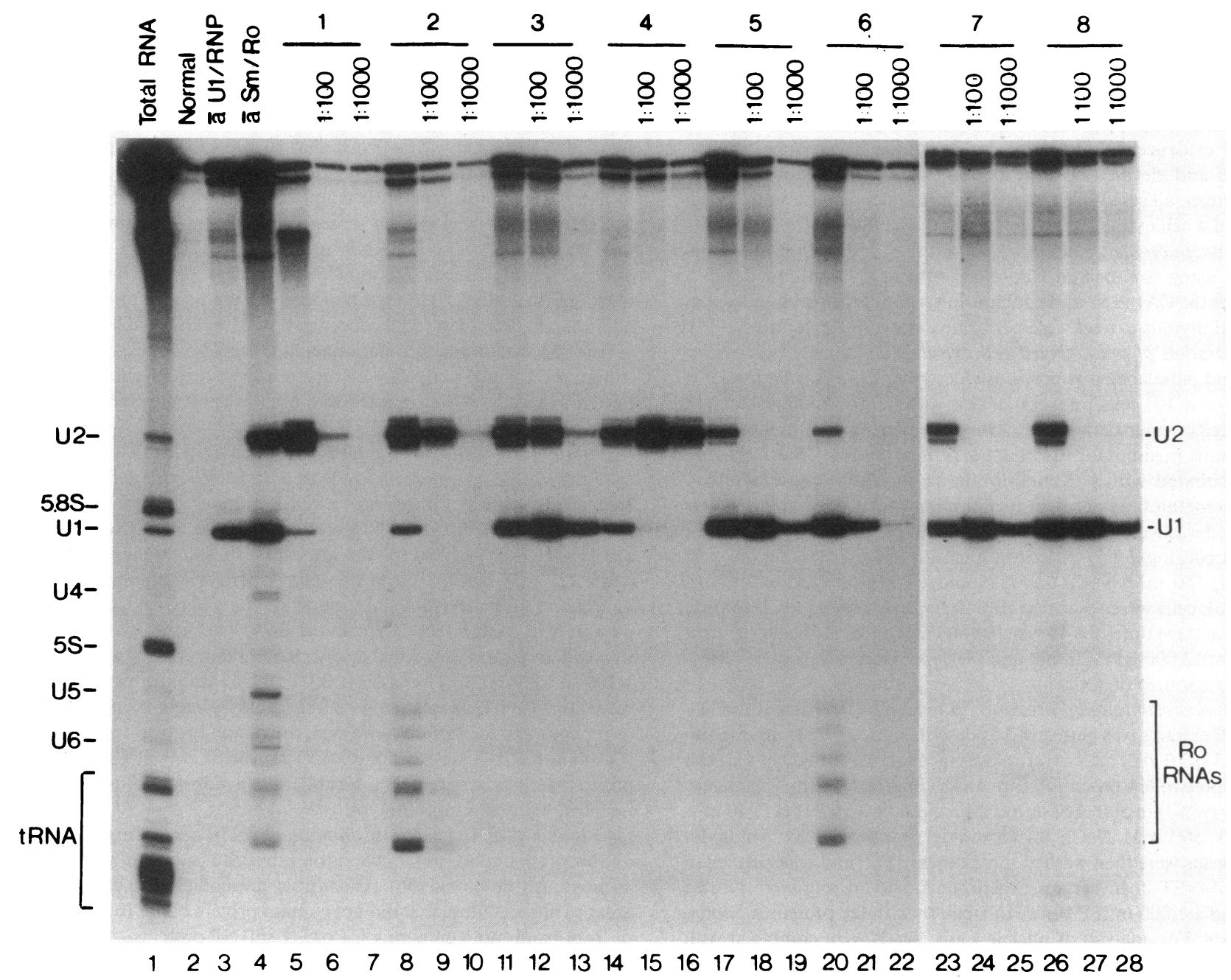

Figure 1. Polyacrylamide gel fractionation of ${ }^{32} \mathrm{P}$-labeled RNAs in a total Hela cell extract (lane 1 ) and after immunoprecipitation by human sera (lanes 2-28). Precipitates were obtained using sera from a normal volunteer (lane 2), from patient controls with anti-U1

other specific for the U2 snRNP. The eighth test serum (serum 3; lane 11) very weakly immunoprecipitated the U4-6 snRNPs, although this binding was faint in comparison to the anti-Sm control (lane 4) and suggested that this serum predominantly contained antibodies to the $\mathrm{U} 1$ and $\mathrm{U} 2$ snRNPs. By immunodiffusion, two of the eight sera (sera 2 and 6) and the anti-Sm control serum also contained anti-Ro antibodies. These sera immunoprecipitated five small RNAs in a pattern typical of the five Ro RNAs (hY1-5) (38).

Since the amounts of U1 and U2 snRNPs in mammalian cells are of the same order of magnitude (16) (compare U2 and U1 RNAs in total cell extract, Fig. 1, lane 1), assays based on serially diluted sera can be used to assess the relative titers of anti-U1 and anti-U2 RNP antibodies. Based upon this approach and as shown in Fig. 1, sera from patients 1, 2, and 4 (lanes 5-10 and 14-16) had titers of anti-U2 RNP greater than the titers of anti-U1 RNP while sera from patients 5-8 (lanes 17-28) had greater titers of anti-U1 RNP antibodies. Serum from patient 3 had high titers of both specificities (lanes 11-13). Diluted sera from patients 1, 2, and 4 were monospecific for U2 snRNP particles.

RNP, and with anti-Sm plus anti-Ro antibodies, respectively (lanes 3 and 4), and from the eight test sera (lanes 5-28). Sera from these eight patients were also screened at dilutions of 1:100 and 1:1000. Lanes 1-22 and lanes 23-28 are from different experiments.

The diagnoses of the 229 patients whose sera were screened are shown in Table I. All eight patients with anti-U2 antibodies had rheumatic disease syndromes that included overlap features. Table II gives a more complete description of these

Table I. Diagnoses of Patients Whose Sera Were Screened for Anti-U2 Antibodies

\begin{tabular}{lc}
\hline \multicolumn{1}{c}{ Diagnosis } & $\begin{array}{c}\text { Number of patients with } \\
\text { anti-U2 antibodies/total } \\
\text { number of patients }\end{array}$ \\
\hline SLE & $0 / 141$ \\
Scleroderma & $0 / 16$ \\
Polymyositis & $0 / 24$ \\
MCTD & $3 / 14$ \\
SLE and/or scleroderma plus myositis & $5 / 34^{*}$ \\
Total & $8 / 229$ \\
\hline
\end{tabular}

\footnotetext{
* Patient 2 (Table II) with esophageal hypomotility and polymyositis was included in this group.
} 
Table II. Diagnoses of Patients with Anti-U2 Antibodies

\begin{tabular}{lcl}
\hline \multicolumn{1}{c}{ Patient no. and diagnosis } & Myositis* & Immunodiffusion \\
\hline $\begin{array}{l}\text { 1. SLE and polymyositis } \\
\text { 2. Polymyositis and esophageal }\end{array}$ & + & UP \\
$\quad$ hypomotility & + & UP \\
3. SLE and scleroderma plus & & \\
$\quad$ erosive polyarthritis & - & UP, RNP \\
4. Scleroderma and polymyositis & + & UP \\
5. Scleroderma and polymyositis & + & RNP \\
6. MCTD & + & RNP \\
7. MCTD & - & RNP \\
8. MCTD & + & RNP \\
& & \\
\hline
\end{tabular}

Abbreviations: +, presence of myositis; -, absence of myositis; UP, unidentified precipitin line, all of which showed identity; RNP, precipitin line that showed identity with a known anti-U1 RNP serum. * Patients 1, 2, and 4-6 had elevations in CPK and proximal muscle weakness; patients 2, 4, and 5 also had electromyograms and/or muscle biopsies consistent with the diagnosis of polymyositis. Clinical information other than the diagnosis of MCTD plus polymyositis was unavailable on patient 8 .

eight patients. Four had either scleroderma (patients 3-5) or marked lower esophageal hypomotility consistent with scleroderma (patient 2). Three of these also had polymyositis, as documented by proximal weakness, abnormal CPK levels, and abnormal electromyograms and/or muscle biopsies; the fourth had SLE and erosive polyarthritis. Two others (patients 1 and 6) had either SLE or MCTD plus proximal weakness and abnormal CPK values, although electromyograms or muscle biopsies were not performed. The final two patients ( 7 and 8 ) had MCTD, including one with myositis although the clinical records of this diagnosis were unavailable. Thus, of the eight patients, six had evidence for an inflammatory muscle disease as documented by at least proximal weakness and elevated CPK levels.

In immunodiffusion, the four sera with high titers of antiU2 antibodies produced a unique precipitin band that showed identity, and that had partial identity with the anti-Sm control serum, but lacked identity with an anti-U1 RNP control. This band is likely related to the anti-U2 antibodies in these sera (25). All eight sera produced speckled nuclear staining when tested in indirect immunofluorescence.

Protein antigens bound. To identify the specific protein antigens bound by these eight sera, we performed immunoblots using substrates enriched for either U1 or U2 snRNPs. HeLa cell extracts were circulated over an anti-U1 affinity column to obtain a preparation of U1 RNP proteins (Fig. 2, stained substrate lanes). The column flow-through was then circulated over an anti-U2 column prepared with serum from patient 1 to obtain a fraction enriched in U2 snRNPs (Fig. 2, stain). In Fig. 2 it can be seen that a control serum containing

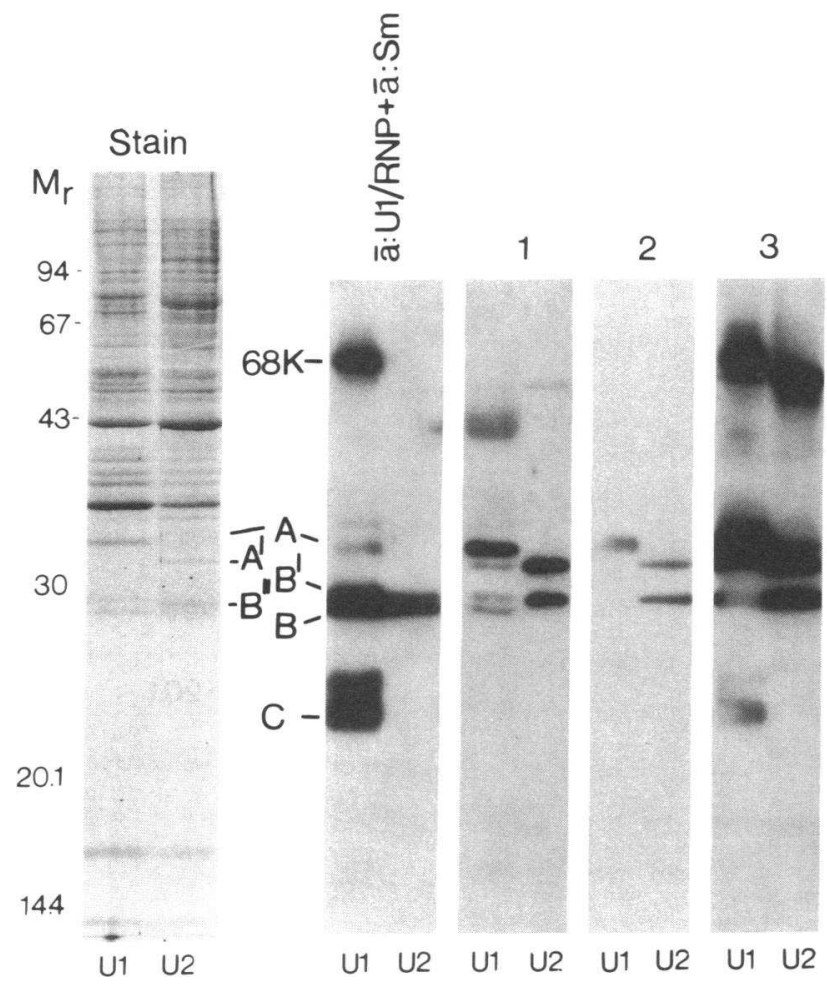

Figure 2. Immunoblots of affinity-purified $\mathrm{U} 1$ and $\mathrm{U} 2 \mathrm{snRNP}$ substrates using a serum from a patient control which contains anti-U RNP plus anti-Sm antibodies, the eight test sera (labeled $1-8$ at the top of the figure), and a serum from a normal volunteer. The total substrate proteins, after transfer to nitrocellulose and staining with amido black, are shown at the left. The positions of the U1 RNPspecific polypeptides $68 \mathrm{~K}, A$, and $C$, the U2-specific polypeptides $A^{\prime}$ and $B^{\prime \prime}$, and the $B^{\prime} / B$ polypeptides (common to the $U 2, U 1$, and

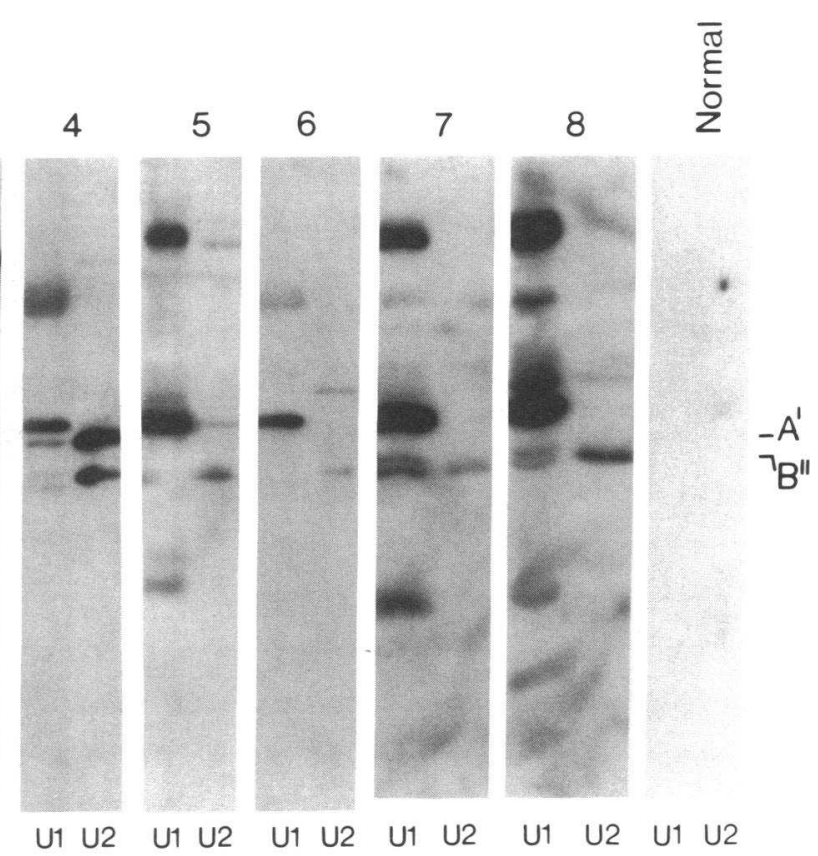

U4-U6 snRNPs) are noted. The Sm control serum did not contain antibodies to the $\mathrm{D}$ polypeptide. The band of $\sim 50,000 \mathrm{D}$ seen in the U1 substrate lane with sera $1,3,4$, and 6-8 is the heavy chain of IgG that eluted off the affinity column and is bound by ${ }^{125}$ I-protein A. Immunoblots done with sera from patients 7 and 8 were from a different SDS-polyacrylamide gel than those performed with the other sera shown. 
both anti-U1 RNP and anti-Sm antibodies binds the U1-specific polypeptides $68 \mathrm{~K}, \mathrm{~A}$, and $\mathrm{C}$ within the $\mathrm{U} 1$ snRNP substrate but not in the $\mathrm{U} 2$ substrate, indicating relative depletion of the U1 particles in the latter substrate. Polypeptides B'/B are bound in both antigen preparations, since these two proteins are components of both U1 and U2 snRNPs. The eight test sera recognized the A polypeptide within the U1 snRNP. enriched substrate. Sera from patients $1,2,4$, and 6 recognized only this U1 RNP component while sera 3, 5, 7, and 8 (which had the highest anti-U1 RNP titers; compare the U1 bands in Fig. 1 when the sera are diluted) also bound the $68 \mathrm{~K}$ and $\mathrm{C}$ polypeptides. Sera $1,3,4,7$, and 8 also bound the $B^{\prime} / B$ polypeptides in the U1 snRNP substrate lane.

The anti-U2 activity of the test sera was directed against both U2-specific polypeptides $A^{\prime}$ and $B^{\prime \prime}$. In immunoblots using the $\mathrm{U} 2$ snRNP substrate, sera with high titers of anti-U2 antibodies bound $A^{\prime}$ and $B^{\prime \prime}$ (Fig. 2, sera 1-4), while sera with lower titers of anti-U2 antibodies recognized only $B^{\prime \prime}$ (sera 5-8). Sera 1,3 , and 4 also bound the U2-specific $A^{\prime}$ protein in the U1 substrate lane, indicating some contamination of this preparation with U2 snRNP proteins.

Two-dimensional immunoblots. To be certain that we were able to distinguish the U2-specific polypeptide B" from the B'$^{\prime} / \mathbf{B}$ polypeptides which migrate closely on one-dimensional gels, we performed nonequilibrium $\mathrm{pH}$ gradient two-dimensional gels and immunoblots using substrates eluted from an anti-Sm immunoaffinity column. These substrates contained all of the polypeptides found in the U1 and U2 snRNPs. Serum from patient 5 bound the U2-specific protein B", as well as the $68 \mathrm{~K}$ and $A$ proteins because of its anti-U1 RNP speci- ficity (Fig. $3 A$ ). The $\mathrm{B}^{\prime} / \mathrm{B}$ polypeptides were bound when the same nitrocellulose strip was reprobed with an anti-Sm serum and were clearly distinguished from $B^{\prime \prime}$ by their more basic isoelectric points (Fig. $3 B$ ) (26). Although this control serum did not contain antibodies to $\mathrm{B}^{\prime \prime}$, this polypeptide was still visualized since antibodies from the anti-U2 serum (Fig. $3 A$ ) remained bound. Similar immunoblots were performed with two other anti-U2 sera with identical results (data not shown).

Structural relationships of the $A^{\prime}$ and $B^{\prime \prime}$ polypeptides. Previous studies had demonstrated that both the $A^{\prime}$ and $B^{\prime \prime}$ polypeptides resided on or near the $3^{\prime}$ end of the U2 RNA $(39,40)$. Since there appeared to be linkage in the immune response to these two polypeptides in our study, we investigated whether they were physically associated on the U2 RNA. As shown in Fig. 4, anti-U2 RNP antibodies on protein A-Sepharose beads bound intact U2 snRNP particles from native extracts of $\left[{ }^{35}\right.$ S]methionine-labeled HeLa cells (lane 1). The identification of the $\mathrm{B}^{\prime \prime}$ polypeptide in these experiments was confirmed by two-dimensional gels (data not shown). When these immunoprecipitates were cleaved with pancreatic ribonuclease, polypeptides $\mathrm{A}^{\prime}$ and $\mathrm{B}^{\prime \prime}$ remained bound to the antibodies (lane 3 ), while the other polypeptides of the $\mathrm{U} 2$ particle $\left(B^{\prime} / B, D-G\right)$ were released into the supernatant and could be recovered by trichloroacetic acid precipitation (lane 4 ). When supernatants of similar immunoprecipitates were precipitated with TCA prior to enzyme digestion, no polypeptides were recovered (lane 2).

Since the apparent resistance to ribonuclease digestion could be explained by the presence of both anti-A' and anti-B" antibodies in our serum, we performed the same digestion

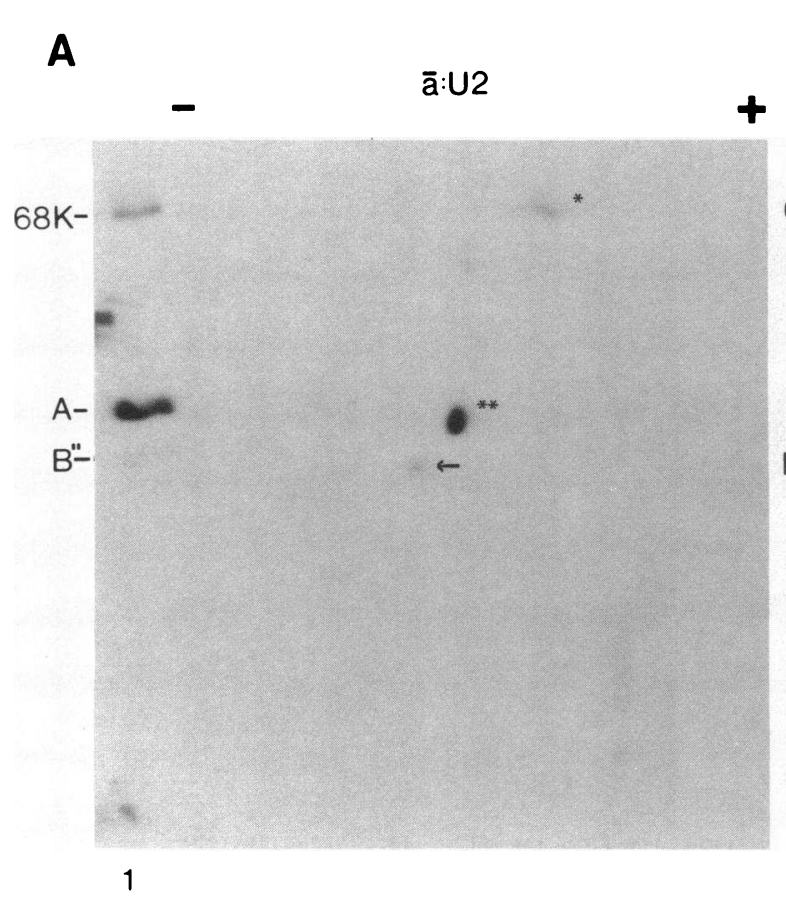

Figure 3. Two-dimensional immunoblot of a substrate obtained by affinity-purification over a column with anti-Sm specificity. $(A)$ In the second dimension, the positions of the polypeptides recognized by serum from patient 5 (Table II and Fig. 2) include $68 \mathrm{~K}(*)$, A (**), and B" (single arrow). For comparison, the far left lane in $A$ (lane 1) contains an identical substrate that has been fractionated in one dimension on the same gel and probed simultaneously with

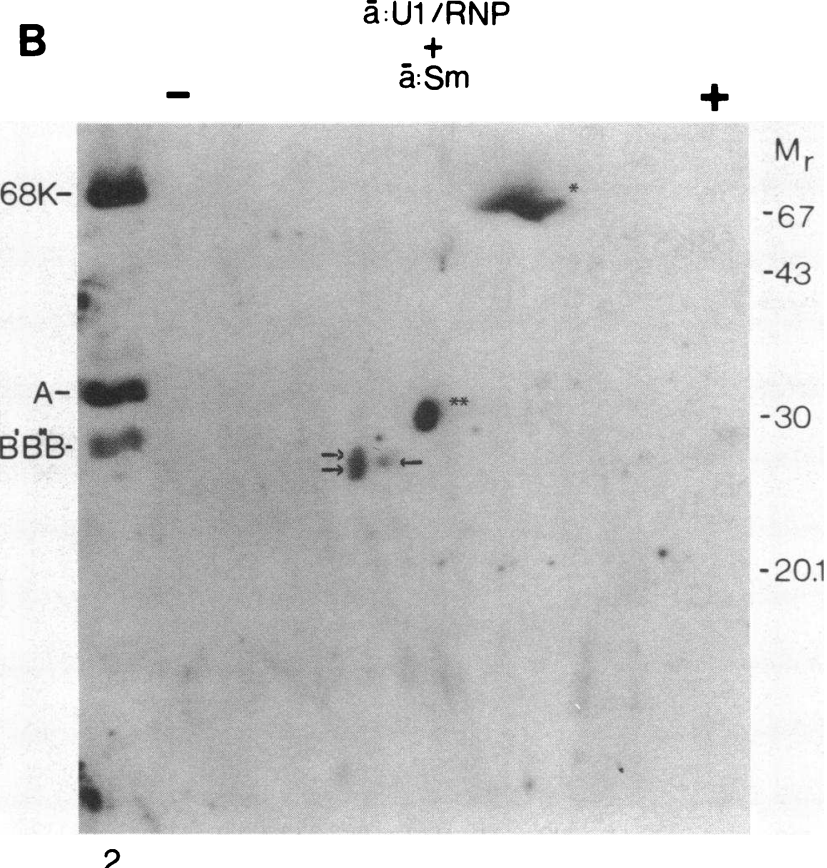

2

serum from patient 5. (B) After autoradiography, the nitrocellulose sheet shown in $A$ was reprobed with a patient control serum containing anti-U1 RNP plus anti-Sm antibodies. The positions of the polypeptides recognized include $68 \mathrm{~K}(*), \mathrm{A}(* *), \mathrm{B}^{\prime \prime}$ (single arrow), and $\mathrm{B}^{\prime} / \mathrm{B}$ (double arrow). The proteins fractionated in one dimension and blotted are also shown (lane 2). 


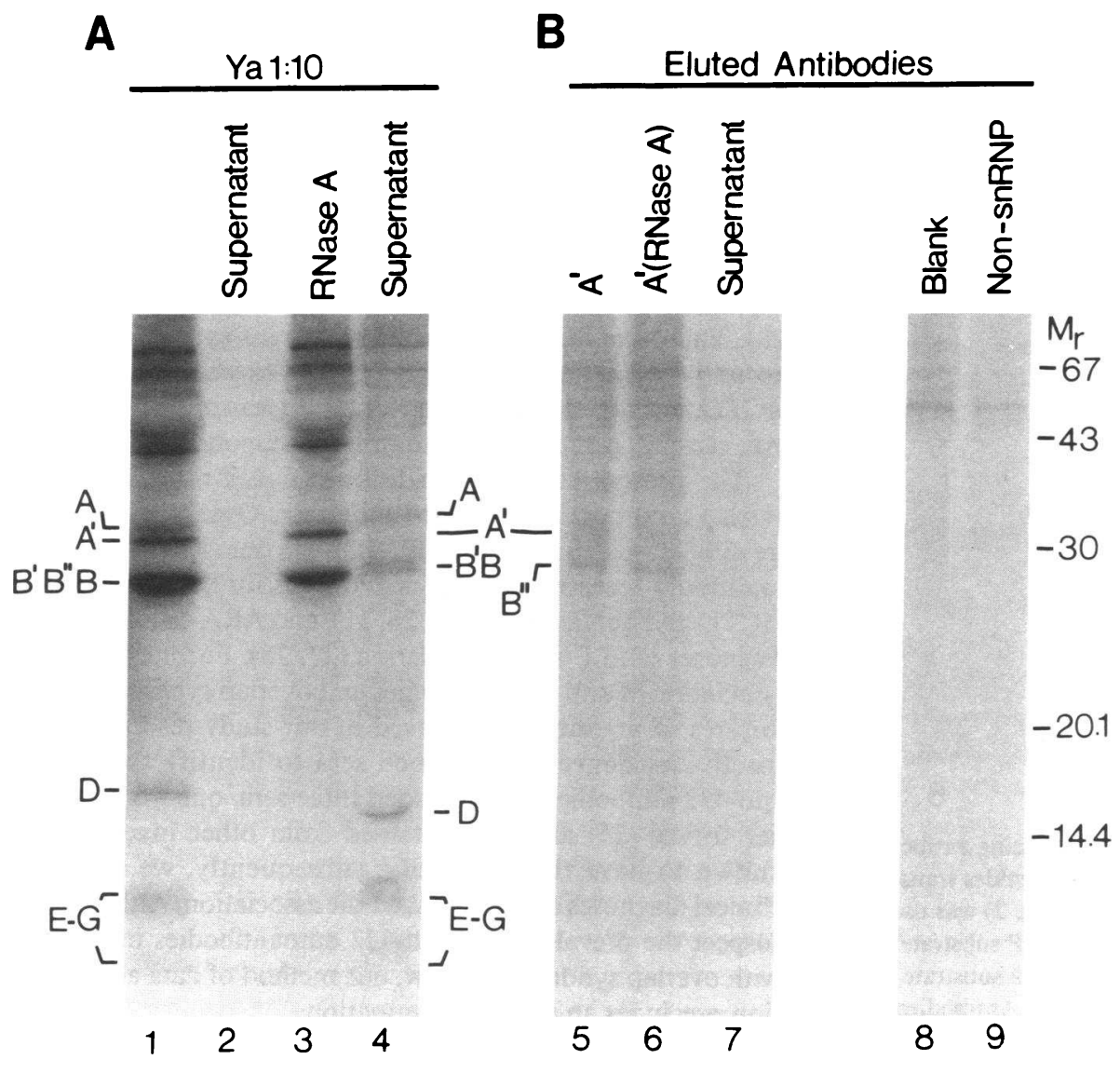

Figure 4. Polyacrylamide gel fractionation of ${ }^{35} \mathrm{~S}$-labeled HeLa cell extracts immunoprecipitated using an anti-U2 serum and using antibodies affinity-purified from the same serum by elution from polypeptides transferred to nitrocellulose. $(A)$ The prototype anti-U2 serum Ya (25) from patient 4 (Table II and Fig. 2) precipitates the U2-specific polypeptides $A^{\prime}$ and $B^{\prime \prime}$ as well as the other polypeptides ( $B^{\prime} / B$ and $\left.D-G\right)$ bound to the U2 RNA (lane 1). This serum at a 1:10 dilution also weakly immunoprecipitates the A polypeptide of the U1 snRNP. The heavily labeled band where the $\mathrm{B}^{\prime} / \mathrm{B}^{\prime \prime} / \mathrm{B}$ polypeptides migrate is $\mathrm{B}^{\prime \prime}$ as demonstrated by twodimensional gels of ${ }^{35}$ S-labeled immunoprecipitates (data not shown). After RNase digestion, the $\mathrm{A}^{\prime}$ and $\mathrm{B}^{\prime \prime}$ polypeptides are still bound (lane 3 ), but the other polypeptides are released and recovered in the supernatant (lane 4); none are recovered in control supernatants prior to RNase digestion (lane 2). The position of the $D$ polypeptide in lane 4 is shifted downward by the unlabeled ribonuclease protein recovered by TCA precipitation. (B) Antibodies affinity-purified by elution from the $A^{\prime}$ band of an immunoblotted nitrocellulose strip (see Fig. 5) also precipitate both the $A^{\prime}$ and $B^{\prime \prime}$ polypeptides (lane 5). After RNase digestion, both poly-

peptides are still bound (lane 6) and not recovered in the supernatant (lane 7). Antibodies eluted from an area of nitrocellulose not containing bands or containing a non-snRNP protein do not immunoprecipitate any proteins (lanes 8 and 9).

experiment using antibodies that were affinity purified from immunoblots. As expected, antibodies purified from the $A^{\prime}$ band immunoprecipitated both the $A^{\prime}$ and $B^{\prime \prime}$ polypeptides since they both were attached to the U2 RNA (lane 5); the other polypeptides of the U2 snRNP were not visualized due to the small concentration of affinity-purified antibodies available to perform this experiment. After ribonuclease digestion, both proteins were still bound by these anti- $\mathrm{A}^{\prime}$ specific antibodies (lane 6) and not recovered in the supernatant (lane 7), suggesting that these two proteins were physically associated. Alternatively, they may be separated by a segment of RNA that is inaccessible to the relatively small pancreatic ribonuclease enzyme $\left(M_{\mathrm{r}}=\right.$ approximately $\left.13,600 \mathrm{D}\right)$. As controls, antibodies eluted from a blank area of nitrocellulose or from a non-snRNP protein (lanes 8 and 9 ) did not bind any polypeptides.

This result could also be explained by the presence of a cross-reactive epitope on the $A^{\prime}$ and $B^{\prime \prime}$ polypeptides. To test this possibility, we performed immunoblots using immunoaffinity-purified antibodies. As shown in Fig. 5, antibodies eluted from the $A^{\prime}$ band only reblotted the $A^{\prime}$ polypeptide. Thus this polypeptide had a unique epitope not shared by $B^{\prime \prime}$, a finding consistent with previous data (26). Additionally, antibodies eluted from $B^{\prime \prime}$ did not recognize the $A^{\prime}$ polypeptide but did react with the A polypeptide of the U1 particle (and vice versa), consistent with the observation that these two polypeptides share a cross-reactive epitope $(26,41)$.

\section{Discussion}

The present study demonstrates that sera from 8 of 229 patients with various rheumatic diseases contain antibodies that are specific for the $A^{\prime}$ and $B^{\prime \prime}$ polypeptides of the U2 snRNP. All eight of the sera were donated by patients with features of an overlap syndrome, including three with documented myositis and three with clinical evidence for this disorder. Thus, autoimmune responses to these polypeptides appear to be particularly common in sera from patients with overlap syndromes with features of myositis.

The present work defines in more detail the patterns of autoimmune responses to the $U 1$ and $U 2$ snRNP particles. We distinguished two different autoantibody systems that independently bind the $A^{\prime}$ and $B^{\prime \prime}$ polypeptides of the U2 snRNP particle and demonstrated that these antibodies occur in an ordered hierarchy (anti-B" responses occurred in all patients, anti- $A^{\prime}$ responses occurred in a subset). Not surprisingly, sera with both specificities more effectively immunoprecipitated the native $U 2$ particle from extracts of Hela cells and could be indentified by immunodiffusion using the appropriate control sera. The enzyme digestion studies shown in Fig. 4 indicated that the $A^{\prime}$ and $B^{\prime \prime}$ polypeptides are closely associated on the $U 2$ RNA and reside as a complex even after this particle is a victim of nuclease attack. In addition, anti-U1 responses were linked to anti-U2 responses as four of the eight test sera contained antibodies to the $68 \mathrm{~K}$ and $C$ polypeptides of the U1 snRNP. 


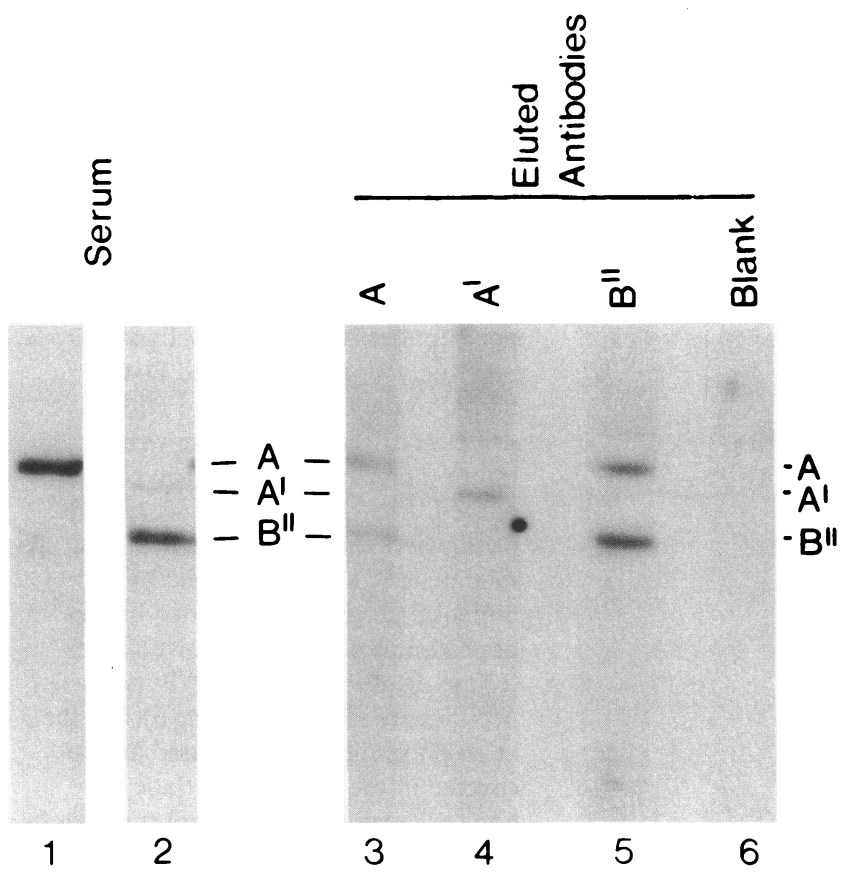

Figure 5. Immunoblot using an anti-U2 serum and using antibodies derived from the same serum by elution from polypeptides transferred to nitrocellulose. Serum from patient 4 (see Fig. 2) was used to probe a $U 1$ snRNP substrate (lane 1 ) and a $U 2$ snRNP substrate (lane 2). Eluted antibodies were then used to reprobe a substrate containing both $U 1$ and $U 2$ snRNP proteins (lanes 3-6). Antibodies eluted from either the A or B" bands reblot both these polypeptides (lanes 3 and 5), while antibodies eluted from $\mathrm{A}^{\prime}$ only reblot $\mathrm{A}^{\prime}$ (lane 4). Antibodies eluted from an area of nitrocellulose without specific bands do not reblot (lane 6). The nitrocellulose strips in lanes 3-6 were exposed approximately four times longer than those in lanes 1 and 2.

Thus these findings provide two examples of linked autoantibody sets that target macromolecular structures, providing further support for the concept that relatively intact nucleoprotein particles elicit their corresponding autoimmune responses (42).

Previous studies of the U2 particle began in 1983 when methods for its biochemical purification were developed $(12-14)$. These studies demonstrated that the U2 particle lacked the $68 \mathrm{~K}, \mathrm{~A}$, and $\mathrm{C}$ polypeptides of the U1 snRNP, shared the $B^{\prime} / B$ and $D-G$ polypeptides common to the Useries of snRNPS, and in addition contained a unique polypeptide subsequently called $A^{\prime}$. Specific autoantibody responses to the U2 snRNP particle were first noted in 1984 with the description of serum Ya from a patient with sclerodermapolymyositis overlap syndrome (25). Through the use of this serum, the presence of the $A^{\prime}$ protein was confirmed, and a second unique polypeptide, $\mathrm{B}^{\prime \prime}$, was tentatively identified. Subsequently sera from four additional patients with antibodies to the U2 particle were described (26). Studies with these sera confirmed the presence of $B^{\prime \prime}$ on this snRNP, showed that this polypeptide shared an epitope with the A protein of the $U 1$ snRNP, and demonstrated a unique epitope on the $A^{\prime}$ polypeptide of the U2 snRNP particle.

The association of antibodies to extractable nuclear antigen (now known to be the anti-U1 RNP specificity) with MCTD was first noted in 1971 (19) and has been corroborated in subsequent studies $(20,21)$. A particularly strong association between high titers of antibodies to the $68 \mathrm{~K}$ polypeptide of the U1 RNP particle and MCTD has been demonstrated more recently $(22,28)$. Similarly, there is an association between MCTD and antibodies to a nuclear matrix protein of identical molecular mass (43). In addition, anti-U2 antibodies have been detected in sera from patients with overlap syndromes, including two patients with psoriasis complicated by Raynaud's phenomenon (27) and six patients with MCTD (28). Thus, like SLE (anti-Sm) (4), Sjögrens syndrome (antiRo, anti-La) (4), and scleroderma (anti-topoisomerase 1) (44), MCTD and other overlap syndromes appear to be associated with certain characteristic autoimmune responses.

The present study which links anti-U2 responses with overlap syndromes has certain limitations. Overlap syndromes are difficult to define rigorously, although our criteria included commonly accepted symptoms and signs for the diagnoses of MCTD and polymyositis $(20,28,31)$, and ARA criteria for the diagnoses of SLE and scleroderma (27, 28). Furthermore, the association of anti-U2 antibodies and overlap syndromes with features of myositis we observed in our study rests on retrospective evidence: we screened sera to identify those with anti-U2 antibodies, and included three sera, one from an earlier survey (25) and two obtained from other investigators, known to have this specificity; subsequently, we reviewed clinical diagnoses and established the association. Although we suspect the prevalence of anti-U2 autoantibodies in patients with overlap syndromes is low, our method of data accumulation precludes an exact determination.

Several of the eight test sera bound the $\mathrm{B}^{\prime} / \mathrm{B}$ polypeptides (Fig. 2) even though only one of these sera (serum 3 ) had even weak anti-Sm activity as determined by immunoprecipitation of ${ }^{32} \mathrm{P}$-labeled cell extracts (Fig. 1). These results possibly reflect binding to a U1 RNP-specific epitope found on the $\mathbf{B}^{\prime} / \mathbf{B}$ proteins $(16,22)$. Alternatively, these sera might recognize epitopes of $B^{\prime} / B$ normally hidden in intact $U 1$ particles and exposed under SDS denaturation, or these sera might contain low levels of anti-Sm antibodies not detectable by the ${ }^{32} \mathrm{P}$-immunoprecipitation assay.

We have proposed that nucleoprotein particles themselves are the focus of the multiple linked sets of antibodies that target each particle (42). The linkage of anti-U2 RNP and anti-U1 RNP antibodies is consistent with the observation that the $U 1$ and $U 2$ snRNPs are associated during the splicing of premessenger RNA (1). Likewise, the complex of heterogeneous nuclear RNP (hnRNP) and the U1 snRNP formed during splicing events provides a potential target for the linked autoantibodies directed toward these particles $(45,46)$. The linkage of anti- $\mathrm{A}^{\prime}$ and anti- $\mathrm{B}^{\prime \prime}$ antibodies demonstrated in this study may be related to the observation that these two proteins remain closely associated after the particle is partially degraded. Similarly, the $\mathbf{B}^{\prime} / \mathbf{B}$ polypeptides that constitute the target of anti-Sm antibodies remain tightly associated to one another and to their RNA after denaturation in SDS (18). Thus, intact splicing complexes and/or partially degraded snRNP particles might act as autoimmunogens to produce the ANA patterns observed here and in other studies.

It is unclear why the $U 2$ specific polypeptides $\left(A^{\prime}\right.$ and $\left.B^{\prime \prime}\right)$ are less common autoantigens than the $U 1$ specific polypeptides $(68 \mathrm{~K}, \mathrm{~A}$, and $\mathrm{C})$ or the $\mathrm{Sm}$ polypeptides $\left(\mathrm{B}^{\prime} / \mathrm{B}\right.$ and $\left.\mathrm{D}\right)$ that are shared among the U1, U2, U4-6 snRNPs. All of these polypeptides are components of snRNP particles that are en- 
gaged in the common function of processing new premessenger RNA transcripts, although the polypeptides themselves may have different stoichiometric relationships with their respective RNAs $(9,12)$. Variations in their stabilities, or perhaps in their structural features, including the degree of exposure or the degree of conservation $(47,48)$, are likely to be important determinants of how they function as autoantigens. The relationship of the autoantigenic epitopes on the U1 and U2 snRNPs and amino acid sequence information derived from current cloning efforts in a number of laboratories (49-52) could yield important insights into fundamental mechanisms of autoimmunity.

\section{Acknowledgments}

We thank Jack Keene, Morris Reichlin, Mitsuo Homma, and Robert Eisenberg for graciously providing sera and clinical information on patients. We are also grateful to Mark Mamula, Janine Evans, Yasuo Ohosone, Gilles Boire, and Cristina Brunet for their careful perusal of the manuscript.

This work was supported in part by grants from the National Institutes of Health (AM 32549-02 and AM 07107-11), the Arthritis Foundation and its Connecticut chapter, the Lupus Foundation of America and its Connecticut chapter, the Scleroderma Society of New York, and a generous donation from the Permut Family. Joe Craft is a Pew Scholar in the Biomedical Sciences.

\section{References}

1. Black, D. L., B. Chabot, and J. A. Steitz. 1985. U2 as well as U1 small nuclear ribonucleoproteins are involved in premessenger RNA splicing. Cell. 42:737-750.

2. Sharp, P. A. 1987. Splicing of messenger RNA precursors. Science (Wash. DC). 235:766-771.

3. Lerner, M. R., and J. A. Steitz. 1979. Antibodies to small nuclear RNAs complexed with proteins are produced by patients with systemic lupus erythematosus. Proc. Natl. Acad. Sci. USA. 76:5495-5499.

4. Tan, E. M. 1982. Autoantibodies to nuclear antigens (ANA): their immunobiology and medicine. Adv. Immunol. 33:167-240.

5. Takano, M., P. F. Agris, and G. C. Sharp. 1980. Purification and biochemical characterization of nuclear ribonucleoprotein antigen using purified antibody from serum of a patient with mixed connective tissue disease. J. Clin. Invest. 65:1449-1456.

6. White, P. J., W. D. Gardner, and S. O. Hoch. 1981. Identification of the immunogenically active components of the Sm and RNP antigens. Proc. Natl. Acad. Sci. USA. 78:626-630.

7. Takano, M., S. S. Golden, G. C. Sharp, and P. F. Agris. 1981. Molecular relationships between two nuclear antigens, ribonucleoprotein and Sm: purification of active antigens and their biochemical characterization. Biochemistry. 20:5929-5936.

8. Liautard, J. P., J. Sri-Wadada, C. Brunel, and P. Jeanteur. 1982. Structural organization of ribonucleoproteins containing small nuclear RNAs from HeLa cells. J. Mol. Biol. 162:623-643.

9. Kinlaw, C. S., S. K. Dusing-Swartz, and S. M. Berget. 1982. Human $\mathrm{U} 1$ and $\mathrm{U} 2$ small nuclear ribonucleoproteins contain common and unique polypeptides. Mol. Cell. Biol. 2:1159-1166.

10. Conner, G. E., D. Nelson, R. Wisniewolski, R. G. Lahita, G. Blobel, and H. G. Kunkel. 1982. Protein antigens of the RNA-protein complexes detected by anti-Sm and anti-RNP antibodies found in serum of patients with systemic lupus erythematosus and related disorders. J. Exp. Med. 156:1475-1485.

11. Matter, L., K. Schopfer, J. A. Wilhelm, T. Nyffenegger, R. F. Parisot, and E. M. De Robertis. 1982. Molecular characterization of ribonucleoprotein antigens bound by antinuclear antibodies. Arthritis Rheum. 25:1278-1283.

12. Hinterberger, M., I. Pettersson, and J. A. Steitz. 1983. Isolation of small nuclear ribonucleoproteins containing U1, U2, U4, U5, and U6 RNAs. J. Biol. Chem. 258:2604-2613.

13. Kinlaw, C. S., B. L. Robberson, and S. M. Berget. 1983. Fractionation and characterization of human small nuclear ribonucleoproteins containing U1 and U2 RNAs. J. Biol. Chem. 258:7181-7189.

14. Bringmann, P., J. Rinke, B. Appel, R. Reuter, and R. Luhrmann. 1983. Purification of snRNPs U1, U2, U4, U5, and U6 with 2,2,7-trimethylguanosine-specific antibody and definition of their constituent proteins reacting with anti-Sm and anti-(U1) RNP antisera. EMBO (Eur. Mol. Biol. Organ.) J. 2:1129-1135.

15. Wooley, J. C., L. R. Zukerberg, and S. Chung. 1983. Polypeptide components of human small nuclear ribonucleoproteins. Proc. Natl. Acad. Sci. USA. 80:5208-5212.

16. Pettersson, I., M. Hinterberger, T. Mimori, E. Gottlieb, and J. A. Steitz. 1984. The structure of mammalian small nuclear ribonucleoproteins. J. Biol. Chem. 259:5907-5914.

17. Billings, P. B., and S. O. Hoch. 1984. Characterization of $U$ small nuclear RNA-associated proteins. J. Biol. Chem. 259:1285012856.

18. Bringmann, P., and R. Luhrmann. 1986. Purification of the individual snRNPs U1, U2, U5 and U4/U6 from HeLa cells and characterization of their protein constituents. EMBO (Eur. Mol. Biol. Organ.) J. 5:3509-3516.

19. Sharp, G. C., W. S. Irvin, R. L. LaRoque, C. Velez, V. Daly, A. D. Kaiser, and H. R. Holman. 1971. Association of autoantibodies to different nuclear antigens with clinical patterns of rheumatic disease and responsiveness to therapy. J. Clin. Invest. 50:350-359.

20. Sharp, G. C., W. S. Irvin, E. M. Tan, R. G. Gould, and H. R. Holman. 1972. Mixed connective tissue disease-an apparently distinct rheumatic disease syndrome associated with a specific antibody to an extractable nuclear antigen (ENA). Am. J. Med. 52:148-159.

21. Sharp, G. C., W. S. Irvin, C. M. May, H. R. Holman, F. C. McDuffie, E. V. Hess, and F. R. Schmid. 1976. Association of antibodies to ribonucleoprotein and $\mathrm{Sm}$ antigens with mixed connective tissue disease, systemic lupus erythematosus and other rheumatic diseases. N. Engl. J. Med. 295:1149-1154.

22. Habets, W. J., D. J. de Rooij, M. H. Hoet, L. B. van de Putte, and W. J. van Venrooij. 1985. Quantitation of anti-RNP and anti-Sm antibodies in MCTD and SLE patients by immunoblotting. Clin. Exp. Immunol. 59:457-466.

23. Reeves, W. H., D. E. Fisher, R. G. Lahita, and H. G. Kunkel. 1985. Autoimmune sera reactive with $\mathrm{Sm}$ antigen contain high levels of RNP-like antibodies. J. Clin. Invest. 75:580-587.

24. Mattioli, M., and M. Reichlin. 1973. Physical association of two nuclear antigens and mutual occurrence of their antibodies: the relationship of the Sm and RNA protein (Mo) systems in SLE sera. $J$. Immunol. 110:1318-1324.

25. Mimori, T., M. Hinterberger, I. Pettersson, and J. A. Steitz. 1984. Autoantibodies to the U2 small nuclear ribonucleoprotein in a patient with scleroderma-polymyositis overlap syndrome. J. Biol. Chem. 259:560-565.

26. Habets, W., M. Hoet, P. Bringmann, R. Luhrmann, and W. van Venrooij. 1985. Autoantibodies to ribonucleoprotein particles containing U2 small nuclear RNA. EMBO (Eur. Mol. Biol. Organ.) J. 4:1545-1550.

27. Reeves, W. H., D. E. Fisher, R. Wisniewolski, A. B. Gottlieb, and N. Chiorazzi. 1986. Psoriasis and Raynaud's phenomenon associated with autoantibodies to $\mathrm{U} 1$ and $\mathrm{U} 2$ small nuclear ribonucleoproteins. N. Engl. J. Med. 315:105-111.

28. Pettersson, I., G. Wang, E. I. Smith, H. Wigzell, E. Hedfors, J. Horn, and G. C. Sharp. 1986. The use of immunoblotting and immunoprecipitation of $(U)$ small nuclear ribonucleoproteins in the analysis of sera of patients with mixed connective tissue disease and systemic lupus erythematosus. Arthritis Rheum. 29:986-995.

29. Tan, E. M., A. S. Cohen, J. F. Fries, A. T. Mase, D. J. McShane, N. F. Rothfield, J. G. Schaller, N. Talal, and R. J. Winchester. 1982. The 1982 revised criteria for the classification of systemic lupus erythematosus. Arthritis Rheum. 25:1271-1277. 
30. Masi, A. T., G. P. Rodnan, T. A. Medsger, Jr., R. D. Altman, W. A. D'Angelo, J. F. Fries, E. C. LeRoy, A. B. Kirsner, A. H. Mackenzie, D. J. McShane, A. R. Myers, and G. C. Sharp. 1980. Preliminary criteria for the classification of systemic sclerosis (scleroderma). Arthritis Rheum. 23:581-590.

31. Bohan A., and J. B. Peter. 1975. Polymyositis and dermatomyositis. N. Engl. J. Med. 292:344-347.

32. Garvey, J. S., N. E. Cremer, and D. H. Sussdorf. 1977. Gel diffusion. In Methods in Immunology. 3rd edition. J. S. Garvey, N. E. Cremer, and D. H. Sussdorf, editors. W. A. Benjamin, Inc., Reading, MA. 313-321.

33. Mimori, T., J. A. Hardin, and J. A. Steitz. 1986. Characterization of the DNA-binding protein antigen Ku recognized by autoantibodies from patients with rheumatic disorders. J. Biol. Chem. 261:2274-2278.

34. Laemmli, U. K. 1970. Cleavage of structural proteins during the assembly of the head of bacteriophage T4. Nature (Lond.). 227:680-685.

35. Towbin, H., T. Staehlin, and J. Gordon. 1979. Electrophoretic transfer of proteins from polyacrylamide gels to nitrocellulose sheets: procedure and some applications. Proc. Natl. Acad. Sci. USA. 76:4350-4354.

36. Smith, D. E., and P. A. Fisher. 1984. Identification, developmental regulation, and response to heat shock of two antigenically related forms of a major nuclear envelope protein in Drosophila embryos: application of an improved method for affinity purification of antibodies using polypeptides immobilized on nitrocellulose blots. $J$. Cell Biol. 99:20-28.

37. O'Farrell, P. Z., H. M. Goodman, and P. H. O'Farrell. 1977. High resolution two-dimensional electrophoresis of basic as well as acidic proteins. Cell. 12:1133-1142.

38. Hendrick, J. P., S. L. Wolin, J. Rinke, M. R. Lerner, and J. A. Steitz. 1981. Ro small cytoplasmic ribonucleoproteins are a subclass of La ribonucleoproteins: further characterization of the Ro and La small ribonucleoproteins from uninfected mammalian cells. Mol. Cell Biol. 1:1138-1149.

39. Mattaj, I. W., and E. M. De Robertis. 1985. Nuclear segregation of U2 snRNA requires binding of specific snRNP proteins. Cell. 40:111-118.

40. Mattaj, I. W., W. J. Habets, and W. J. van Venrooij. 1986. Monospecific antibodies reveal details of U2 snRNP structure and interaction between U1 and U2 snRNPs. EMBO (Eur. Mol. Biol. Organ.) J. 5:997-1002.
41. Reuter, R., C. F. Lehner, E. A. Nigg, and R. Luhrmann. 1986. A monoclonal antibody specific for snRNPs U1 and U2. FEBS (Fed. Eur. Biochem. Soc.) Lett. 201:25-30.

42. Hardin, J. 1986. The lupus autoantigens and the pathogenesis of systemic lupus erythematosus. Arthritis Rheum. 29:457-460.

43. Habets, W. J., D. J. de Rooij, M. H. Salden, A. P. Verhagen, C. A. G. van Eekelen, L. B. van de Putte, and W. J. van Venrooij. 1983. Antibodies against distinct nuclear matrix proteins are characteristic for mixed connective tissue disease. Clin. Exp. Immunol. 54:265-276.

44. Shero, J. H., B. Bordwell, N. Rothfeld, and W. C. Earnshaw. 1986. High titers of autoantibodies to topoisomerase I (Scl-70) in sera from scleroderma patients. Science (Wash. DC). 231:737-740.

45. Fritzler, M. J., R. Ali, and E. M. Tan. 1984. Antibodies from patients with mixed connective tissue disease react with heterogeneous nuclear ribonucleoprotein or ribonucleic acid (hnRNP/RNA) of the nuclear matrix. J. Immunol. 132:1216-1222.

46. Hardin, J. A., C. Gelpi, J. Downs, and T. Mimori. 1985. Autoantibodies to hnRNP in patients with SLE. Clin. Res. 33:507A. (Abstr.)

47. Hardin, J. A., and J. O. Thomas. 1983. Antibodies to histones in systemic lupus erythematosus: localization of prominent autoantigens on histones H1 and H2B. Proc. Natl. Acad. Sci. USA. 80:74107414.

48. Kieber-Emmons, T., and H. Kohler. 1986. Evolutionary origin of autoreactive determinants (autogens). Proc. Natl. Acad. Sci. USA. 83:2521-2525.

49. Chambers, J. C., and J. D. Keene. 1985. Isolation and analysis of cDNA clones expressing human lupus La antigen. Proc. Natl. Acad. Sci. USA. 82:2115-2119.

50. Wieben, E. D., A. M. Rohleder, J. M. Nenninger, and T. Pederson. 1985. cDNA cloning of a human autoimmune nuclear ribonucleoprotein antigen. Proc. Natl. Acad. Sci. USA. 82:7914-7918.

51. Theissen, H., M. Etzerodt, R. Reuter, C. Schneider, F. Lottspeich, P. Argos, R. Luhrmann, and L. Philipson. 1986. Cloning of the human CDNA for the U1 RNA-associated 70K protein. EMBO (Eur. Mol. Biol. Organ.) J. 5:3209-3217.

52. Habets, W. J., P. T. G. Sillekens, M. H. Hoet, J. A. Schalken, A. J. M. Roebroek, J. A. M. Leunissen, W. J. M. van de Ven, and W. J. van Venrooij. 1987. Analysis of a cDNA clone expressing a human autoimmune antigen: full-length sequence of the $\mathrm{U} 2$ small nuclear RNA-associated B" antigen. Proc. Natl. Acad. Sci. USA. 84:24212425 . 